\author{
Yu.L. Mazurov, M.V. Slipenchuk \\ Lomonosov Moscow State University, Moscow, Russia \\ Corresponding author: jmazurov@yandex.ru
}

\title{
Legacy of the great plan of environment transformation in Russia
}

\begin{abstract}
In October 1948, a comprehensive long-term plan for the transformation of environment was adopted in the USSR in order to ensure maximum sustainable yields in the main agricultural regions of the country. The project, designed for the period 1949-1965, was developed as a reaction to the consequences of severe 1946 drought, but its content is undoubtedly a strategic document of national importance. The created forest belts and reservoirs had to significantly diversify the flora and fauna of the country. Consequently, the plan combines the tasks of environmental protection and obtaining maximum sustainable yields. The paramount feature of this plan was its thorough scientific support based on the ideas of a whole galaxy of prominent Russian scientists and practitioners. This plan anticipated the emergence of the national concept of rational nature management. It was not fully implemented. However, the very fact of its adoption and partial implementation has become a bright page in the history of domestic land use and an instructive example of a combination of economic, social and environmental interests. Numerous manifestations of this plan legacy in modern conditions are perceived as a multifunctional historical heritage that deserves a high national status.
\end{abstract}

Keywords: legacy, cultural landscapes, agriculture, nature management, environment transformation, heritage sites.

\section{Introduction}

In the history of Russia, there were many projects for the transformation of nature. As a result of their implementation, economic, cultural landscapes of local and regional scale were formed. Among them there are a plenty of landscapes that can rightfully be attributed to the category "Unique economic landscapes" (classification of cultural landscapes of the UNESCO World Heritage Center) or to the category "Standard of environmental management efficiency" (according to the similar classification of V.A. Nikolaev). A special place among such projects belongs to the so-called Stalin's plan for the transformation of nature - one of the most ambitious in world history and throughout the years remains one of the most productive $[1,2]$.

The essence of the plan was the purposeful transformation of agricultural landscapes to ensure their optimal efficiency through scientifically grounded systemic reclamation measures. It so happened that the multi-year program of this project was not fully implemented. However, even in such a situation, this project left behind a kind of historical legacy. One of the manifestations of this heritage is the transformed steppe landscapes on vast territories with such iconic elements as forest belts and water bodies. These landscapes are unmistakably determined from the ground and when observed from the air, clearly visible in aerial photographs and images from space. Essentially, they really ensure the agro-economic stability of the respective regions, convincingly demonstrating the advantages of a scientifically grounded culture of environmental management.

Possessing features of objects of mixed natural and cultural heritage, these landscapes, with rare exceptions, do not have the corresponding status. However, in our opinion, they undoubtedly deserve it due to their value from the standpoint of the history of nature management and ecological culture. To confirm this thesis, let us take a further historical excursion.

\section{Project background}

Russia is a country with the deep traditions and great achievements in agriculture. For centuries, the Russian peasant fed his country and ensured its export. In many ways, the success of Russian agriculture is associated with the presence of a huge territory of black earth soils in the country - the most fertile lands in the world for growing grain and the most other popular crops. At the same time, unfortunately, the entire territory of the country is located in the so-called "zone of risky farming". The risks in it are associated with numerous natural disasters, the worst of which is drought - the ruthless enemy of the Russian countryside and its peasants for centuries. 
Drought in Russia is not such a rare occurrence indeed. Yet, sometimes its scale reaches the dimensions of a national catastrophe, manifested in the spread of hunger in the places of this disaster and the death of tens and hundreds of thousands of people from it. Such catastrophes, in particular, were the droughts of 1891 and 1921. Nevertheless, the drought of 1946, which hit a huge part of the country, was the most terrible in its consequences. The situation was aggravated by the dire consequences of the just-ended war with fascist Germany and its European satellites.

In these conditions, the government of the country decides to take radical measures to prevent similar phenomena in the future. It attracts leading specialists in the USSR to develop an unprecedented project of guaranteed provision of favorable natural conditions for the development of agriculture in the main agricultural zones of the country (Fig. 1). In modern times, it could be called a sustainable agriculture program.

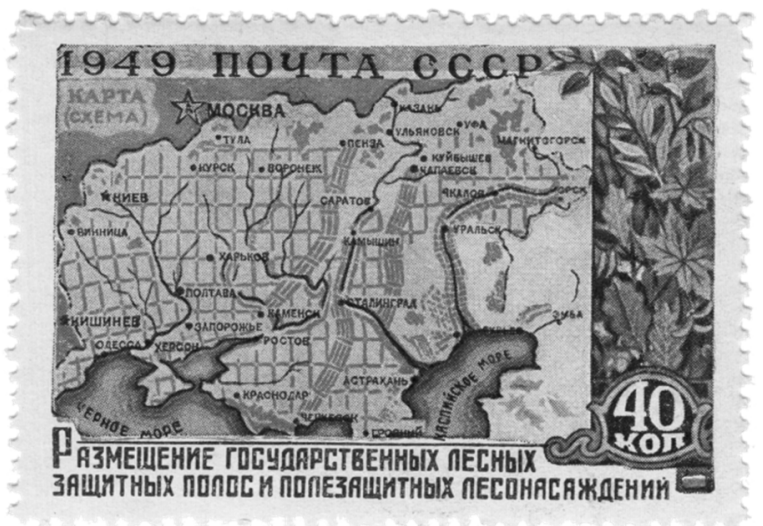

Figure 1. Schematic map of the 1948 environment transformation plan on the Soviet post stamp*

\section{Plan and Its Context}

In October 1948, authorities of the USSR adopted a comprehensive long-term plan for the transformation of nature in order to ensure maximum sustainable yields in the main agricultural regions of the country. In terms of its economic, environmental, and geographical characteristics, this plan had no precedent in either domestic or world history. The project, designed for the period 1949-1965, was developed as a reaction to the consequences of the severe drought of 1946, but in its content it was undoubtedly a strategic document of national importance [3].

Despite the noted circumstances, this plan still remains ignored by analysts of the history of environmental management. The initial reasons for this annoying fact are likely to lie in the political aspects of the life of Russian society. It is believed that the named plan was developed and adopted on the initiative of the Soviet leader Josef Stalin. Almost immediately, it received in society the title "Stalin's plan for the transformation of nature", which reflected both its essence and status (Fig. 2).

The immediate goal of the plan was to prevent droughts, sand and dust storms in the southern regions of the USSR (Western Kazakhstan, the Volga Region, the North Caucasus, Eastern Ukraine). In accordance with this plan, it was necessary to change the climate on an area of 120 million hectares, equal to the territories of Britain, France, Italy, Belgium and the Netherlands combined.

The central place in the plan was occupied by field-protective afforestation and irrigation. In total, it was planned to reforest more than 4 million hectares of the territory and create state field-protection belts with a length of over $5300 \mathrm{~km}$ [4]. These strips were supposed to protect the fields from hot southeastern winds - dry winds. In addition to the state forest protective belts, forest belts of local importance were planted along with the perimeter of individual fields, the slopes of ravines, existing and newly created reservoirs on the sands (Fig. 3).

\footnotetext{
${ }^{*}$ Hereinafter, photographs and scans of the authors and from open sources on the Internet.
} 


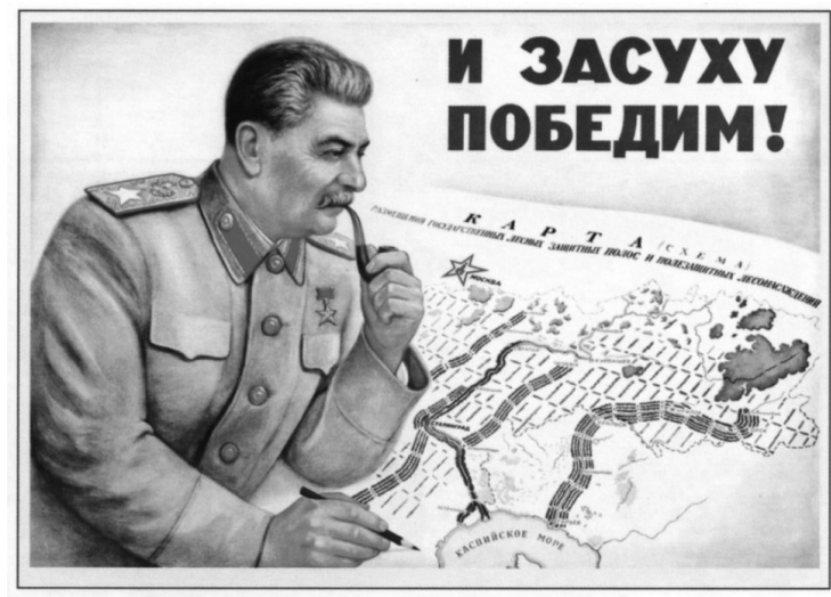

Figure 2. Poster of the end of 1940th "Win the Drought"

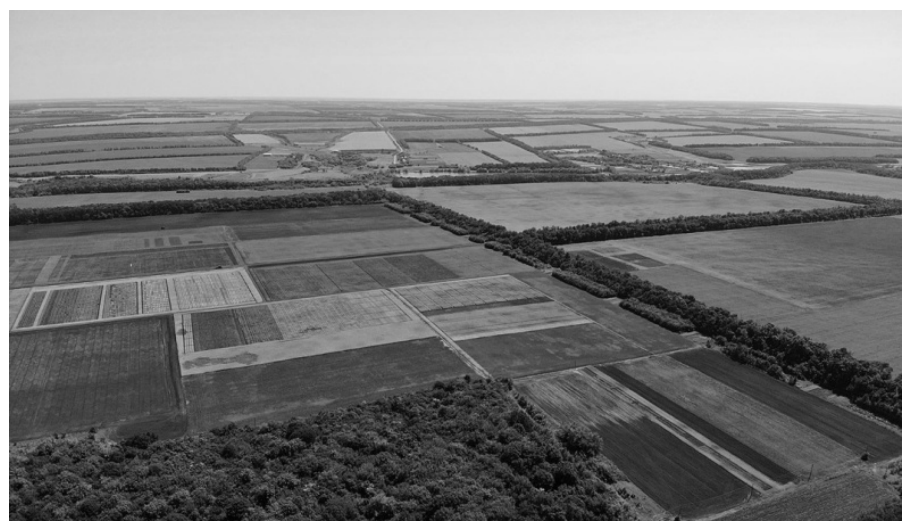

Figure 3. Field protection forest belts

The plan also provided for the introduction of a grass farming system developed by the outstanding Russian scientists P.A. Kostychev and V.R. Williams. According to this system, part of the arable land in crop rotations was sown with perennial legumes and bluegrass grasses. Herbs served as a fodder base for animal husbandry and a natural means of restoring soil fertility.

The taken measures have led to a significant increase in grain yield. As a result of an increase of investment in agriculture and an improvement in the technical equipment of collective and state farms, it was possible to create a solid forage base for the development of animal husbandry.

The plan envisaged not only absolute food self-sufficiency of the Soviet Union, but also building up the export of domestic grain and meat products from the second half of the 1960s. The created forest belts and reservoirs had to significantly diversify the flora and fauna of the USSR. Thus, the plan combines the tasks of environmental protection and obtaining maximum sustainable yields.

\section{Scientific support}

The most important feature of the 1948 plan was its thorough scientific support, based on the ideas of a whole pleiad of prominent Russian scientists and practitioners of agriculture. The leading place among them rightfully belongs to the professor of St. Petersburg University Vasily Dokuchaev - the founder of modern soil science (Fig. 4).

In 1892, a year after a terrible drought that engulfed almost the entire black earth zone of European Russia, he published the book "Our Steppes Before and Now". In this book, he simply and clearly explained the causes of steppe droughts, which he saw not so much changes in natural conditions as in the predatory nature management of that time, in the depletion of the natural fertility of chernozem (black) soils. There he also proposed and substantiated a coherent system of measures that could protect the steppe zone of Southern Russia from crop failures. 


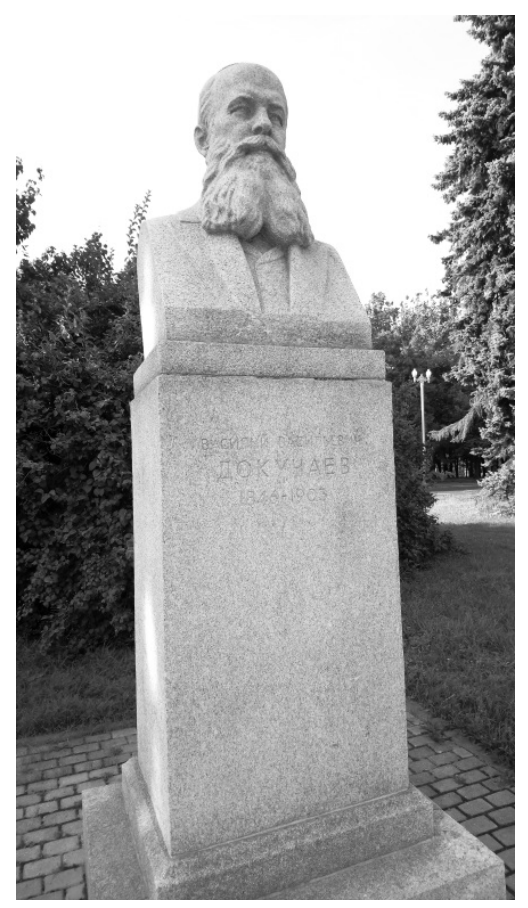

Figure 4. Monument to V.V. Dokuchaev in Moscow near the Moscow State University

Dokuchaev's system is based on his idea of "harmony with nature" and includes [3]:

- regulation of runoff of large and small rivers and arrangement of local water basins for irrigation of adjacent lands;

- securing ravines with the help of forest plantations, wattle fences and hedges, arranging ponds to retain snow and rainwater, in order to irrigate the underlying slopes and the bottom of the gullies, prohibiting plowing of steep slopes;

- regulation of watersheds using a system of shallow ponds, rows of hedges for accumulating snow and retaining spring and rainwater;

- afforestation of all sands, mounds and generally uncomfortable plots for arable land;

- development of norms that determine the relative areas of arable land, meadows, forests and waters, that is, the correct organization of steppe territories;

- application of the most favorable methods of soil cultivation for the use of moisture and adaptation of varieties of cultivated plants to local soil and climatic conditions.

Having developed a program for combating drought and having organized a number of experimental sites for many years of testing their proposals, Dokuchaev created the basis for that grandiose plan for transforming the nature of the steppes. The scientist understood that the program he proposed to combat drought was a national task. However, it was impossible to implement it in the conditions of pre-revolutionary Russia. The ideas of the great Russian scientist about the radical transformation of the nature of the steppes were in demand only after 50-60 years, under the conditions of a planned socialist economy with the active scientific support within the framework of a national project.

\section{Implementation of the plan}

The implementation of the plan began almost immediately after the adoption of the government decree. Among other things, this was facilitated by the active work deployed in the country to clarify the meaning of the plan. Prominent scientists, university professors, municipal and regional authorities, cultural figures and the media took an active part in it (Fig. 5). The topic of this plan has become one of the main points in the country's information and educational policy. Nature conservation courses have become ubiquitous in university curricular. In the field of education, the topic of nature conservation and transformation has dramatically expanded its presence. 


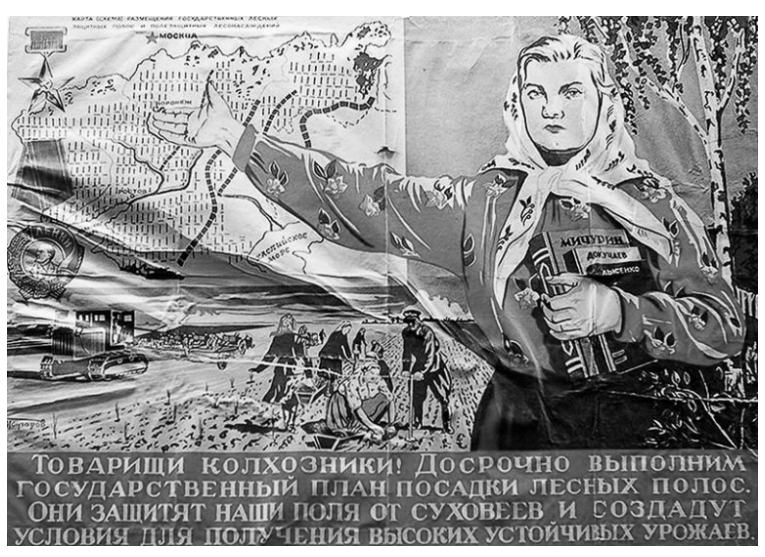

Figure 5. Poster encouraging participation in the implementation of the forest planting plan

The adopted plan received the broadest public support. Undoubtedly, this was facilitated by its popularization. However, the paramount factor was conscious support of this plan on the part of the country's peasants. As bearers of traditional ecological culture, they saw in this government project a reflection of the popular ideas of increasing the efficiency of agriculture based on centuries of experience. The urban population, most of which at that time were peasants in their very recent past, did not remain aloof from this project.

The most important advantage of this long-term plan was the possibility of obtaining economic results literally from the first years of the creation of its infrastructure. So, it actually happened. By 1952, the infrastructure envisaged by the plan was basically created and started to work. The quality of agricultural lands, protected by forest belts and provided with modern reclamation, gradually increased - erosion decreased, water balance was ensured, and as a result, the yield of fields and the productivity of forage lands increased. The taken measures have led to an increase in the yield of grain crops by $30 \%$, vegetables - by $50-75 \%$, herbs - by 100-200\%. The situation changed in full accordance with the scientific forecast, which promised the country a significant progress in the agricultural sector and environmental well-being.

\section{The fate of the plan and its meaning}

However, with the death of Stalin in 1953, the fulfillment of the plan was curtailed. Many forest belts were cut down, several thousand ponds and reservoirs for fish farming were abandoned; hundreds of forest protection stations created in 1949-1955 were eliminated. Instead of the Stalin's plan, the new Soviet leader Nikita Khrushchev put forward another plan based on increasing the production of grain crops due to the development of virgin lands. Unfortunately, this plan was not scientifically justified, which facilitated its negative environmental consequences, without providing sufficiently targeted economic results.

In spite of being only implemented partially, Stalin's plan for the transformation of nature and its adoption became a bright page in the history of domestic environmental management and an instructive example of the combination of economic, social and environmental interests. The forest belts created at that time firmly fit into the landscape of a number of the most considerable agrarian regions of the country, still ensuring their well-being results (Fig. 6).

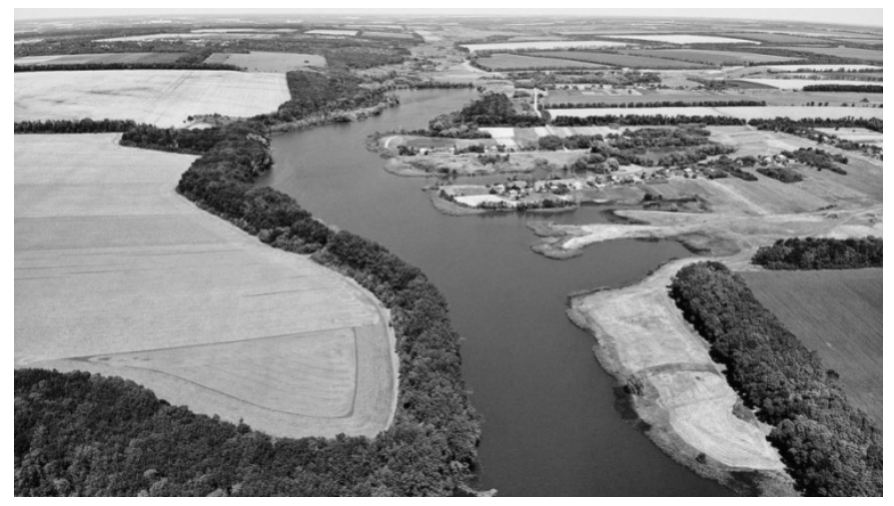

Figure 6. Dokuchaev's heritage, the legacy of the Stalin's plan 
Despite the decades of the actual hushing up of this grandiose national ecological and economic project, a number of its elements have been in demand both in Russia and abroad. Particularly impressive ones are the large-scale afforestation of semi-desert and desert territories in China, as well as in some another countries. At the same time, it seems that many elements of the current forestry policy and environmental policy of this country as a whole are based on the ideas of the scientific heritage of V.V. Dokuchaev and the lessons of the Stalin's Plan for the Transformation of Nature.

\section{Artifacts of Outstanding Land Use Systems as Historical Heritage}

The retrospective analysis undertaken above facilitated to make the following estimates:

- agricultural landscapes formed as a result of the implementation of the Stalin's plan have a stable economic and high historical and cultural value;

- they have been demonstrating their high economic value for about 70 years, which ensures recognition of the effectiveness of the land use systems they have formed;

- historical and cultural value of these landscapes is based on the synthesis of local agricultural traditions with scientifically based innovations;

- culture of farming, formed in the process of the formation of progressive systems of land use, is in demand in modern conditions and in the future, especially in connection with the ongoing climate changes.

These features give reason to consider the artifacts of the project under consideration as a formed phenomenon of heritage, both material (outstanding in terms of their productivity systems of nature management) and intangible (based on the scientific substantiation of V.V. Dokuchaev and other domestic scientists, the experience of effective environmental management). In this case, we can talk both about cultural heritage sites of the national level, and about proposals for the inclusion of especially outstanding cultural landscapes in the World Heritage List. One of the most convincing arguments in favor of the formulated proposal is the presence of such properties on the World Heritage List. Here are some examples (from among those personally surveyed by the author).

One of the most famous and popular World Heritage Sites in Switzerland (Romandy) is the Lavaux Terraced Vineyards (since 2007). The landscape of this World Heritage Site on the northern shore of Lake Geneva is breathtaking in all seasons, attracting a huge number of tourists. It is no coincidence that the image of this landscape is present on the 200-franc note (Fig. 7). However, the Lavaux vineyards became a World Heritage Site not because of their aesthetic merits. They were nominated for the World Heritage list by the government of this country as a unique example of centuries-old interaction between man and the environment, focused on the optimal use of local resources for the production of high-quality agricultural products. In this case, it is wine, which is highly valued here and plays an important role in the economy of the region.

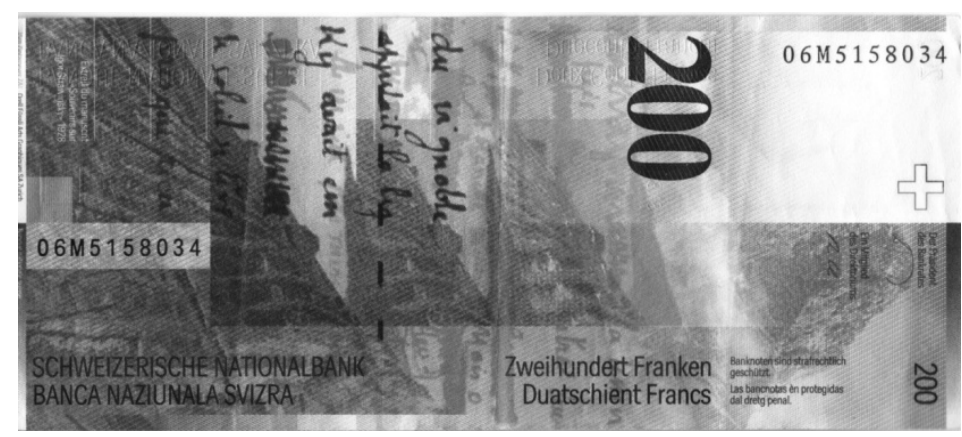

Figure 7. Lavaux vineyard landscape on a Swiss banknote

Lavaux vineyards are nominated according to three criteria: iii (demonstrating the cultural traditions of extinct or modern civilizations), iv (unique buildings or architectural ensembles, including landscape) and $\mathrm{v}$ (a prime example of a traditional settlement or land use system). The World Heritage List took into account that "local communities actively support measures to protect nature, thereby striving to counter the threat of galloping urbanization".

Another illustrative example of this kind is the Indonesian site "Cultural Landscape of Bali Province: Subak System as a Manifestation of the Tri Hit Karana Philosophy" (2012). Subak is a traditional water management-based agricultural (terraced rice) system that has shaped the modern landscape of Bali (Fig. 8). 
It is believed that it is this system that has allowed the Balinese to become the most successful rice growers in the archipelago.

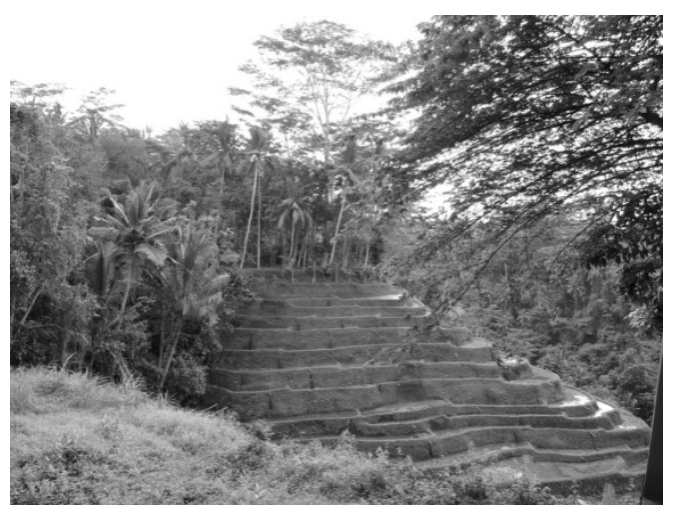

Figure 8. Bali Subak system landscape

Subak was included in the world heritage according to four criteria: ii (unique object of architecture, monumental art, urban planning, as well as especially valuable areas of the cultural landscape), iii (see above), v (see above) and vi (demonstration of modern ideas, beliefs, trends in art, living traditions of mankind).

The list of such objects in the world heritage can be significantly extended. At the same time, these examples are enough to be convinced of the possibility of interpreting the artifacts of the Stalinist plan for the transformation of nature as a heritage phenomenon that fully coincides with the criteria for identifying the cultural heritage of UNESCO.

In this regard, we believe that the time has come for the recognition of the nature management sphere formed in the course of the implementation of the largest project in Russian history as a phenomenon of historical heritage. The inclusion of the artifacts of this project (in one form or another) in the register of national cultural heritage is also becoming relevant. In addition, it is legitimate to raise the question of our country nominating an object associated with this project and having a symbolic meaning.

There are many options for choosing such an object. As an example, let us point out the State Nature Reserve of federal significance "Kamennaya Steppe" with an area of 5232 hectares [4]. It is located in the Talovsky district of the Voronezh region, on the watershed of the Bityug and Khoper River basins and was created on May 25, 1996 by a decree of the Government of the Russian Federation. This protected area has the profile of an integrated (landscape) reserve. It was created to protect the unique semi-cultural foreststeppe landscapes. On the territory of the reserve, undisturbed classic chernozem soils have been preserved. It is also important that this reserve is directly related to the research of V.V. Dokuchaev. An experimental agricultural station named after this great scientist operates on its territory. The history of this "Dokuchaevsky oasis" is connected with another outstanding scientist of our country - Academician N.I. Vavilov, who worked here in the 1920s.

\section{Conclusions}

Stalin's plan for the transformation of nature is perceived in our time as an outstanding event in the history of nature management in Russia. His project received an unprecedented scientific basis, it was enthusiastically supported by the entire vast country. It has become one of the national development priorities. However, the fate of this plan turned out to be dramatic; it was actually curtailed without any real reason [5-7].

At the same time, its story is highly instructive. This plan largely anticipated the emergence of the domestic concept of rational nature management and, to a certain extent, the Western concept of sustainable development. This is especially true for our time - the era of transition to a "green" economy as the main condition for sustainable development.

This plan left behind numerous valuable artifacts, a kind of legacy of the scientific ideas of great scientists and a grandiose implemented project. Now, after seven decades, this legacy is increasingly perceived as the historical legacy of Russia, and possibly of neighboring countries - Kazakhstan and Ukraine. 
1 Войцеховский М. Государственный лесной пояс / М. Войцеховский // Независимая газета. - 2008. - 26 нояб.

2 Саушкин Ю.Г. Великий план по трансформации природы / Ю.Г. Саушкин // Вопросы географии. - Вып. 28. Проблемы физической географии в связи с большими строительными проектами коммунизма. — М.: Географгиз, 1952. C. $11-41$.

3 Голубчиков Ю.Н. Первая в мире глобальная агроэкологическая программа (к 70-летию «Сталинского плана преобразования природы») / Ю.Н. Голубчиков // Экологические и географические исследования в бассейнах рек: материалы 5-й Всерос. науч.-практ. конф. - Воронеж: Воронеж. гос. пед. ун-т, 2018. — С. 145-148.

4 Шипунов Ф. Докучаевские «бастионы» / Ф. Шипунов // Чувство земли: советские ученые и писатели о защите родной природы, об экологии управления. - М.: Мысль, 1988. — С. 22-74.

5 Марченко Н. Рассекреченная история. Великий план преобразования природы. [Электронный pecypc]. URL: http://tvkultura.ru/video/show/brand_id/31793/episode_id/2042658/.

6 Mazurov Y. Great Plan of Environmental Transformation: from the history of nature management in Russia / Y. Mazurov // Explore Rural India. — 2021. - Vol. 8, Iss. 1. — P. 41-44.

7 Панфилов В.Ф. Лесные бастионы / В.Ф. Панфилов. - М.: Природа, 2004. — 135 с.

\author{
Ю.Л. Мазуров, М.В. Слипенчук
}

\title{
Ресейдегі қоршаған ортаны трансформациялаудың ұлы жоспарының мұрасы
}

1948 жылдың қазан айында КСРО-да елдің негізгі ауылшаруашылық аудандарында жоғары тұрақты өнімділікті қамтамасыз ету үшін қоршаған ортаны қайта құрудың ұзақ мерзімді жоспары қабылданды. 1949-1965 жылдарға арналған жоба 1946 жылғы қатты құрғақшылықтың әсеріне реакция ретінде жасалды, бірақ оның мазмұны сөзсіз мемлекеттік маңызы бар стратегиялық құжат болып табылады. Құралған орман алқаптары мен су қоймалары елдің флорасы мен фаунасын едәуір әртараптандыруы керек еді. Сонымен қатар жоспар қоршаған ортаны қорғау және жоғары тұрақты өнім алу міндеттерін біріктіреді. Бұл жоспардың маңызды ерекшелігі мынада: көрнекті орыс ғалымдары мен практиктерінің идеяларына негізделген, яғни жан-жақты ғылыми қамтамасыз етілуі болды. Бұл жоспар табиғатты ұтымды пайдаланудың ұлттық тұжырымдамасының пайда болуын көздеді, бірақ толық орындалмады. Дегенмен оның қабылдануы мен ішінара жүзеге асырылуының өзі отандық жер пайдалану тарихының жарқын парағы және экономикалық, әлеуметтік және экологиялық мүдделер үйлесімінің тағылымды үлгісі болды. Қазіргі жағдайда осы жоспардың мұрасының көптеген көріністері жоғары ұлттық мәртебеге ие көпфункционалды тарихи мұра ретінде қабылданады.

Кілт сөздер: мұра, мәдени ландшафттар, ауыл шаруашылығы, табиғаттыпайдалану, қоршаған ортаны қайта құру, мұра объектілері.

\section{Ю.Л. Мазуров, М.В. Слипенчук}

\section{Наследие великого плана трансформации окружающей среды в России}

В октябре 1948 г. в СССР был принят Комплексный долгосрочный план преобразования окружающей среды с целью обеспечения высоких устойчивых урожаев, в основных сельскохозяйственных районах страны. Проект, рассчитанный на период 1949-1965 гг., разрабатывался как реакция на последствия сильной засухи 1946 г., но, по своему содержанию, несомненно, являлся стратегическим документом государственной важности. Созданные лесополосы и водоёмы должны были значительно разнообразить флору и фауну страны. Таким образом, план сочетает в себе задачи охраны окружающей среды и получения высоких устойчивых урожаев. Важнейшей особенностью этого плана было его основательное научное сопровождение, основанное на идеях целой плеяды выдающихся российских учёных и практиков. Этот план предполагал появление национальной концепции рационального природопользования, которая не была выполнена в полном объеме. Однако сам факт его принятия и частичного осуществления стал яркой страницей в истории бытового землепользования и поучительным примером сочетания экономических, социальных и экологических интересов. Многочисленные проявления наследия этого плана в современных условиях воспринимаются как многофункциональное историческое наследие, заслуживающее высокого национального статуса.

Ключевые слова: наследие, культурные ландшафты, сельское хозяйство, природопользование, преобразование окружающей среды, объекты наследия. 


\section{References}

1 Voitsekhovsky, M. (2008). Gosudarstvennyi lesnoi poias [State Forest belt]. Nezavisimaia gazeta - Nezavisimaya Gazeta, Nov., 26 [in Russian].

2 Saushkin, Yu.G. (1952). Velikii plan po transformatsii prirody [A great plan for transforming nature]. Voprosy geografii. Vyp. 28. Problemy fizicheskoi geografii v sviazi s bolshimi stroitelnymi proektami kommunizma - Questions of Geography. Issue 28. Problems of physical geography in connection with the great construction projects of communism. Moscow: Geografgiz [in Russian].

3 Golubchikov, Yu.N. (2018). Pervaia v mire globalnaia agroekologicheskaia programma (k 70-letiiu «Stalinskogo plana preobrazovaniia prirody») [The world's first global agro-ecological program (to the 70th anniversary of the "Stalin's plan for the transformation of nature")]. Proceedings from Ecological and geographical research in river basins: 5-ia Vserossiiskaia nauchnoprakticheskaia konferentsiia - Fifth all-Russian scientific-practical conference. Voronezh: Voronezh State Pedagogical University [in Russian].

4 Shipunov, F. (1988). Dokuchaevskie «bastiony» [Dokuchaevskie "bastions"]. Chuvstvo Zemli: sovetskie uchenye i pisateli o zashchite rodnoi prirody, ob ekologii upravleniia - Sense of the Earth: Soviet scientists and writers on the protection of native nature, on the ecology of management. Moscow: Mysl [in Russian].

5 Marchenko, N. Rassekrechennaia istoriia. Velikii plan preobrazovaniia prirody [Declassified history. The great plan for the transformation of nature]. Retrieved from: http://tvkultura.ru/video/show/brand_id/31793/episode_id/2042658 [in Russian].

6 Mazurov, Y. (2021). Great Plan of Environmental Transformation: from the history of nature management in Russia. Explore Rural India, 8 (1); 41-44.

7 Panfilov, V.F. (2004). Lesnye bastiony [Forest bastion]. Moscow: Priroda [in Russian]. 